\title{
Politik Hukum Pembaharuan Undang-Undang Nomor 40 Tahun 2007 tentang Perseroan Terbatas (Kajian Pasal 74 beserta Penjelasannya)
}

\author{
Eko Rial Nugroho \\ Fakultas Hukum Universitas Islam Indonesia \\ Jl. TamansiswaNo. 158 Yogyakarta \\ e_rial76@yahoo.co.id
}

\begin{abstract}
The change of Corporate Social Responsibility (CSR) to be a legal obligation has made CSR become formality to fulfill certain obligations. The drafting process of the Constitution of Limited Company (UU PT), especially related to CSR regulations, has not fully reflected the characteristics of laws which are responsive in the middle of democratic political configuration. Therefore, this research focuses on discussing how the legal politics in the amendment of Consitution No 40 Year 2007 regarding Limited Company especially related to Article 74 which is about Corporate Social Responsibility and its explanations are. This was a normative legal research which was analyzed by using qualitative analysis. The findings show that the drafting process of UU PT has not fully reflected the characterstics of laws which are responsive in the middle of democratic political configuration. CSR regulations in UU PT, practically becoming the characteristics of Indonesian corporation laws, overlap with other existing laws.
\end{abstract}

Keywords: Limited Company, CSR, UUPT, Legal Politics

\begin{abstract}
Abstrak
Perubahan Corporate Social Responsibility (CSR) menjadi kewajiban hukum menyebabkan program CSR bersifat formalitas untuk pemenuhan suatu kewajiban. Proses penyusunan UU Perseroan Terbatas khususnya regulasi CSR, masih belum sepenuhnya mencerminkan karakteristik produk hukum yang responsif atau populistik di tengah pusaran konfigurasi politik yang demokratis. Oleh karena itu, fokus penelitian membahas bagaimana politik hukum dalam pembaharuan Undang-Undang Nomor 40 Tahun 2007 tentang Perseroan Terbatas khususnya terhadap Pasal 74 tentang Corporate Social Responsibility beserta penjelasannya? Penelitian ini merupakan penelitian hukum normatif dan dianalisis dengan menggunakan analisis kualitatif. Penelitian ini menyimpulkan proses pembentukan UU PT, belum sepenuhnya mencerminkan karakteristik produk hukum yang responsif di tengah pusaran konfigurasi politik yang demokratis. Regulasi CSR dalam UU PT, secara praktik realistis menjadi karakteristik hukum korporasi Indonesia tumpang tindih dengan hukum-hukum yang sudah ada.
\end{abstract}

Kata Kunci : Perseroan Terbatas, CSR, UUPT, Politik Hukum 


\section{Pendahuluan}

Salah satu perbedaan yang cukup menonjol antara Undang-Undang Nomor 40 Tahun 2007 tentang Perseroan Terbatas (selanjutnya disebut UU PT) dengan peraturan yang digantikannya (Undang-Undang Nomor 1 Tahun 1995) adalah adanya ketentuan mengenai Tanggung Jawab Sosial dan Lingkungan (selanjutnya disebut TJSL) atau Corporate Social Responsibility (selanjutnya disebut CSR) dalam UU PT. Pencantuman TJSL sebagai suatu syarat yang diwajibkan bagi perseroan sebenarnya merupakan hal yang tidak lazim mengingat konsep CSR (konsep yang diadaptasi menjadi TJSL dalam UU PT) bukanlah ketentuan yang mandatory dalam ketentuan tentang perseroan di negara-negara lain. Di satu sisi, penerapan syarat TJSL (ditambah ketentuan sanksi atas pelanggarannya) dalam UU PT dapat menjadi sarana penekan bagi para pemodal yang selama ini dikenal nakal dalam menjalankan aktivitas bisnisnya. Namun di sisi lain, golongan pengusaha yang selama ini disiplin menerapkan CSR akan merasa kehilangan nilai kesukarelaan dalam setiap aktivitas CSR mereka.

Kalangan bisnis telah menyuarakan penolakan dimasukkannya pasal tentang tanggung jawab sosial perusahaan dalam UU PT yang baru. Kritik yang muncul, bahwa CSR adalah konsep di mana perusahaan, sesuai kemampuannya, melakukan kegiatan yang dapat meningkatkan kesejahteraan masyarakat dan perbaikan lingkungan. Kegiatan itu ada di luar kewajiban perusahaan yang umum dan sudah ditetapkan dalam hukum formal, seperti ketertiban, usaha, pajak atas keuntungan, dan standar lingkungan. Mereka berpendapat, jika diatur, selain bertentangan dengan prinsip kerelaan, CSR juga akan memberi beban baru kepada perusahaan. Apalagi jika keharusan itu ditetapkan di Indonesia yang dikenal hukumnya tidak pasti dan pejabat publiknya korup.

Sikap menolak terhadap pasal yang mewajibkan perusahaan melaksanakan CSR, sangat jelas ditunjukkan oleh sejumlah asosiasi perusahaan yang tergabung dalam Kamar Dagang dan Industri (selanjutnya disebut Kadin) Indonesia. Mereka beralasan CSR yang berlaku wajib dapat membebani industri, menurunkan daya saing, menghambat iklim investasi di dalam negeri, memicu hengkangnya modal dari Indonesia, sehingga dikhawatirkan dapat menurunkan 
ekspor yang berdampak pada meningkatnya angka pengangguran. CSR juga dianggap akan menjadi beban cost bagi perusahaan yang tidak semuanya mendapatkan keuntungan besar. Mereka beranggapan tugas sosial itu cukup dilakukan oleh pemerintah, karena mereka sudah membantunya dalam bentuk pajak. ${ }^{1}$

Selama ini (sebenarnya) sudah ada kesadaran dari perusahaan untuk menerapkan tanggung jawab sosial. CSR sudah menjadi bagian dari strategi bisnis dalam upaya menambah nilai positif perusahaan di mata publik yakni membangun image perusahaan. Beberapa perusahaan bahkan melihat CSR sebagai bagian dari manajemen risiko. Mengembangkan program CSR yang berkelanjutan dan berkaitan dengan bidang usaha merupakan konsekuensi mekanisme pasar. Kesadaran ini menjadi tren global seiring semakin maraknya kepedulian masyarakat global terhadap produk-produk yang ramah lingkungan dan diproduksi dengan memperhatikan kaidah-kaidah sosial dan prinsip-prinsip hak asasi manusia.

Mengenai filosofi dan paradigma dasar, TJSL adalah padanan kata yang digunakan di dalam UU PT untuk penggunaan istilah corporate social responsibility (CSR). CSR atau TJSL sebagai suatu konsep, berkembang pesat sejak 1980-an hingga 1990-an sebagai reaksi dan suara keprihatinan dari organisasi-organisasi masyarakat sipil dan jaringan tingkat global untuk meningkatkan perolaku etis, fairness dan responsibitas perusahaan yang tidak hanya terbatas pada perusahaan, tetapi juga pada para stakeholder dan komunitas atau masyarakat sekitar wilayah kerja dan operasinya. ${ }^{2}$

Ada nilai perusahaan yang terkandung di dalamnya yaitu, pertama, CSR bersifat sukarela, kedua, prinsip etis dan moral, dan ketiga, sifat sukarela mencakup semua sektor, baik badan hukum publik dan privat. CSR adalah prinsip yang bersifat etis dan moral yang dinormakan oleh Pasal 74 UU PT menjadi bersifat kewajiban dan memiliki sanksi bagi yang tidak menjalankan pasal tersebut. Rumusan pasal tersebut bertentangan dengan prinsip dasar CSR

${ }^{1}$ Hidayat, Mohamad, "Pandangan Dunia Usaha terhadap Undang-Undang Nomor 40 Tahun 2007 tentang Perseroan Terbatas," dalam http://www.madani-ri.com, pandangan-dunia-usaha-terhadap-undangundang, diakses tanggal 31 Oktober 2007.

${ }^{2}$ Gunawan Wijaya, Seri Pemahaman Perseroan Terbatas 150 Tanya Jawab tentang Perseroan Terbatas, Cetakan Pertama, Forum Sahabat, Jakarta, 2008, hlm. 96. 
yang bersifat etis, moral, dan sukarela, mengingat konsep CSR merupakan tindakan hukum yang melebihi apa yang dipersyaratkan oleh hukum dan peraturan yang berlaku.

Tindakan penormaan tersebut, menimbulkan kewajiban dan sanksi, yang sesungguhnya menimbulkan ketidakpastian dan kontradiktif karena menyebabkan terjadinya ketidakjelasan antara tanggung jawab yang didasarkan atas karakter sosial, social responsibility yang bersifat sukarela dengan kewajiban hukum yang bersifat dan mempunyai daya memaksa. Perubahan CSR menjadi kewajiban hukum menyebabkan CSR bersifat formalitas untuk pemenuhan suatu kewajiban dan membuat Indonesia menjadi satu-satunya negara di dunia yang mengatur CSR sebagai kewajiban hukum dengan pemberian sanksi.

Pasal 74 tentang CSR muncul, saat pembahasan di tingkat Panitia Kerja (selanjutnya disebut Panja) dan Panitia Khusus (selanjutnya disebut Pansus) DPR. Konsep awal yang diajukan pemerintah, tidak ada pengaturan CSR. Pada acara dengar pendapat dengan pihak Kadin dan para pemangku kepentingan lain, materi Pasal 74 belum ada. Karena pemerintah saat itu, memang berharap dunia usaha melakukan CSR dengan kesadaran sendiri, tidak perlu diatur undang-undang. ${ }^{3}$

Sekilas terlihat, pembentukan dan pencantuman Pasal ini bersifat "mencari popularitas" mengingat pembahasan UU PT ini tidak jauh berselang setelah terjadinya kasus lumpur panas di Sidoarjo. Melalui Pasal 74 ini, legislator di DPR seperti memilih jalan keluar untuk "menghukum" semua perusahaan walaupun hanya satu perusahaan, yaitu Lapindo, yang melakukan keselahan ketika itu.

Para penyusun UU PT di DPR telah membuat regulasi CSR dengan pengetahuan yang sangat minim mengenainya. Hal ini tampak dari tidak jelasnya definisi mengenai CSR serta pemangku kepentingan. Mereka juga tampak tidak paham mengenai perdebatan sifat sukarela dan wajib dari CSR. Hal ini diperparah juga bahwa mereka tidak juga meminta masukan dari pihak-pihak yang berkepentingan maupun mereka yang memiliki pengetahuan, sehingga kewajiban CSR dalam UU PT terkesan merupakan hasil kerja DPR tanpa konsultasi publik sama sekali.

${ }^{3}$ http://pemberdayaan-lifeskill-csr.blogspot.com/2008/05/perdebatan-csr-dimedia-bahan-bagi.html, diakses tanggal 16 Juli 2007. 


\section{Rumusan Masalah}

Adapun rumusan masalah dalam penelitian ini adalah bagaimana politik hukum dalam pembaharuan Undang-Undang Nomor 40 Tahun 2007 tentang Perseroan Terbatas khususnya terhadap Pasal 74 tentang Corporate Social Responsibility beserta penjelasannya?

\section{Tujuan Penelitian}

Adapun tujuan penelitian ini untuk mengetahui politik hukum dalam pembaharuan pembaharuan Undang-Undang Nomor 40 Tahun 2007 tentang Perseroan Terbatas khususnya terhadap Pasal 74 Undang-Undang Nomor 40 Tahun 2007 tentang Perseroan Terbatas beserta penjelasannya.

\section{Metode Penelitian}

Penelitian ini merupakan penelitian hukum normatif, yaitu penelitian yang dilakukan dengan mendasarkan pada data kepustakaan sebagai data utamanya yang merupakan data sekunder dan berupa bahan-bahan hukum. Bahan hukum yang digunakan antara lain Undang-Undang Nomor 40 Tahun 2007 tentang Perseroan Terbatas, Undang-Undang Nomor 25 Tahun 2007 tentang Penanaman Modal (UUPM), Peraturan Pemerintah Nomor 47 Tahun 2012 tentang Tanggung Jawab Sosial dan Lingkungan Perseroan Terbatas, Putusan MK No. 53/PUUVI/2008. Bahan-bahan hukum yang telah dikelompokkan dan diklasifikasikan, selanjutnya dianalisis dengan menggunakan analisis kualitatif. Dengan analisis kualitatif tersebut, langkah-langkah yang ditempuh didasarkan logika yuridis, sehingga permasalahannya dapat dijelaskan dalam penelitian ini.

\section{Hasil Penelitian dan Pembahasan}

Corporate Social Responsility (selanjutnya disebut CSR) berasal dari literatur etika bisnis di Amerika Serikat dikenal sebagai corporate social responsibility atau 
social responsibility of corporation. Kata corporation atau perusahaan telah dipakai dalam bahasa Indonesia yang diartikan sebagai perusahaan, khususnya perusahaan besar. Dilihat dari asal katanya, "perusahaan" berasal dari bahasa Latin "corpus/corpora" yang berarti badan. Dalam sejarah perusahaan dijelaskan bahwa perusahaan itu merupakan suatu badan hukum yang didirikan untuk melayani kepentingan umum (not for profit), namun dalam perkembangannya justru menumpuk keuntungan (for profit). ${ }^{4}$

Menurut World Business Council for Sustainable Development, CSR didefinisikan sebagai "business commitment to contribute to sustainable economic development, working with employees, their families, the local community, and society at large to improve their quality of life." 5 Bank Dunia (The World Bank Group) juga mengartikan CSR "is the commitment of business to contribute to sustainable economic development, working with employees and their representatives, their families, the local community and society at large to improve quality of life, in ways that are both good for business and good for development."6

ISO 26000, sebagai pedoman pelaksanaan CSR secara internasional, mendefinisikan CSR sebagai "responsibility of an organization for the impacts of its decisions and activities on society and the environment, through transparent and ethical behavior that contributes to sustainable development, health and the welfare of society; takes into account the expectations of stakeholders; is in compliance with applicable law and consistent with international norms of behavior; and is integrated throughout the organization and practiced in its relationships."7

Secara lebih jelas dan rinci, Dauman dan Hargreaves dalam Hasibuan mengartikan tanggung jawab perusahaan dengan mengelompokkannya ke dalam tiga macam tanggung jawab yang menyatu, yaitu: ${ }^{8}$ a. Basic Responsibility. Pada level pertama, menghubungkan tanggung jawab yang pertama suatu perusahan,

\footnotetext{
4Priyanto Susiloadi, "Implementasi Corporate Social Responsibility Untuk Mendukung Pembangunan Berkelanjutan,” Jurnal Spirit Publik Volume 4, Nomor 2 Halaman: 123 - 130, Oktober 2008, hlm. 4.

${ }^{5}$ http://www.fias.net/ifcext/economics.nsf/Content/CSR-IntroPage.

${ }^{6}$ Amin Wijaya Tunggal, Business Ethics dan Corporate Social Responsibility (CSR) Konsep dan Kasus, Havarindo, 2008, hlm. 23.

${ }^{7}$ Pamadi Wibowo Jalal dan Sonny Sukada, "Perkembangan Mutakhir CSR di Indonesia: Antara Pasal 74 UUPT dan Draft 4.1. ISO 26000", makalah pada seminar "CSR For Better Indonesia", Lingkar Studi CSR, Bandung, 19 April 2008, hlm. 11.

${ }^{8}$ Hasibuan, "Pengaruh Karakteristik Perusahaan terhadap Pengungkapan Sosial", Tesis, Universitas Diponegoro, Semarang, 2001.
} 
yang muncul karena keberadaan perusahaan tersebut seperti; perusahaan harus membayar pajak, memenuhi hukum, memenuhi standar pekerjaan, dan memuaskan pemegang saham. Bila tanggung jawab pada level ini tidak dipenuhi akan menimbulkan dampak yang sangat serius; b. Organization responsibility (OR). Pada level kedua ini menunjukan tanggung jawab perusahaan untuk memenuhi perubahan kebutuhan "Stakeholder" seperti pekerja, pemegang saham, dan masyarakat di sekitarnya; c. Societal Responses (SR). Pada level ketiga, menunjukan tahapan ketika interaksi antara bisnis dan kekuatan lain dalam masyarakat yang demikian kuat sehingga perusahaan dapat tumbuh dan berkembang secara berkesinambungan, terlibat dengan apa yang terjadi dalam lingkungannya secara keseluruhan.

Dari beragam definisi tersebut di atas dapat disimpulkan bahwa terdapat perusahaan dalam menjalankan roda ekonominya harus senantiasa untuk memperhatikan kondisi sosial dan kesejahteraan para stakeholder khususnya pada masyarakat di sekitar perusahaan.

Konsep CSR merupakan "inisiatif" perusahaan dan merupakan tindakan sukarela. Konsep CSR bagi korporasi sebenarnya mengalami perkembangan, ${ }^{9}$ di mana pada awalnya perusahaan hanya bertanggung jawab kepada pemegang saham saja, sekarang perusahaan juga mempunyai tanggung jawab kepada pekerja, pemasok, masyarakat dan lingkungan di mana perusahaan itu menjalankan kegiatan usahanya. ${ }^{10}$

Pembahasan tentang CSR tidak dapat dilepaskan terhadap persoalan etika bisnis, karena pada dasarnya CSR diderivasi dari etika bisnis. ${ }^{11}$ Secara historis etika sebagai usaha filsafat lahir dari ambruknya tatanan moral di lingkungan kebudayaan Yunani 2500 tahun lalu. Karena pandangan-pandangan lama tentang baik dan buruk tidak lagi dipercayai, para filosof mempertanyakan kembali norma-norma dasar bagi kelakukan manusia. Situasi itu juga berlaku pada zaman sekarang. Etika bukan suatu sumber tambahan bagi ajaran moral, melainkan

${ }^{9}$ Ridwan Khairandy, “Corporate Social Responsibility: Dari shareholder Ke Stakeholder, dan Dari Etika Bisnis Ke Norma Hukum," makalah yang disampaikan pada Workshop Tanggungjawab Sosial Perusahaan, yang diselenggarakan kerjasama PUSHAM UII dengan Norsk Senter for Menneskerettigheter Norwegian Center for Human Rights, 2008, hlm. 4.

${ }^{10} \mathrm{Ibid}$.

${ }^{11}$ Ridwan Khairandy, Op.Cit., hlm. 2 
merupakan filsafat atau pemikiran kritis dan mendasar tentang ajaran-ajaran dan pandangan-pandangan moral. ${ }^{12}$

Dalam konteks yang umum, hubungan bisnis sebenarnya adalah hubungan antar manusia. Bisnis adalah suatu interaksi yang terjadi akibat adanya kebutuhan yang tidak dapat diperoleh sendiri oleh individu. Ini menunjukkan bahwa meskipun manusia dikaruniai banyak kelebihan (akal, perasaan dan naluri), dalam kenyataannya banyak memiliki kekurangan. Kekurangan itu makin dirasakan justru ketika akal, perasaan, dan naluri menuntut peningkatan kebutuhan-kebutuhan. Akibatnya, kebutuhan manusia kian berkembang dan kompleks sehingga tidak terbatas. Melalui interaksi bisnis inilah manusia saling melengkapi pemenuhan kebutuhan satu sama lain. ${ }^{13}$

Nilai-nilai dasar yang menjadi tolak ukur etika bisnis adalah tingkah laku para pengusaha dalam menjalankan usahanya. Apakah dalam usahanya mengambil keuntungan dari masyarakat konsumen dilakukan melalui persaingan usaha yang fair (jujur), transparent (terbuka), dan ethic (etis). Perbuatan yang termasuk dalam kategori unethical conduct misalnya memberikan informasi yang tidak benar mengenai bahan mentah, karakteristik/ciri dan mutu suatu produk, menyembunyikan harta kekayaan perusahaan yang sebenarnya untuk menghindari atau mengurangi pajak, membayar upah karyawan, melakukan persekongkolan tender, dan melakukan persaingan tidak sehat. ${ }^{14}$

Pada dasarnya, bisnis perlu dijalankan secara etis, karena bagaimana pun juga bisnis menyangkut tentang kepentingan siapa saja dalam masyarakat. Hal itu berarti bahwa kita semua, berdasarkan kepentingan kita masing-masing, menghendaki adanya agar bisnis itu berjalan dengan baik. Oleh karena itu, kita semua menghendaki agar bisnis dijalankan secara etis sehingga tidak ada salah satu pihak yang merasa dirugikan oleh pihak lain.

Doktrin CSR yang dilahirkan sebagai suatu etika atau moral dalam perilaku perusahaan, sudah banyak diterima dalam berbagai peraturan perundang-undangan, meskipun istilah CSR mempunyai makna berbeda dengan

${ }^{12}$ Franz Magniz Suseno, Etika Dasar: Masalah-Masalah Pokok Filsafat Moral, Penerbit Kanisius, Yogyakarta, 1987, hlm 15. Lihat juga Ridwan Khairandy, Op.Cit., hlm. 2.

${ }^{13}$ Redi Panuju, Etika Bisnis, PT Grasindo, Jakarta, 1995, hlm 42.

${ }^{14}$ Ridwan Khairandy, Op.Cit. hlm. 2-3. 
etika, moral, philantrophi, dan hukum. CSR mewakili kompromi antara etika dan perilaku-perilaku tertentu, di mana CSR diciptakan untuk meningkatkan kesan baik perusahaan di dalam masyarakat di mana perusahaan itu menjalankan kegiatan usahanya. Ide untuk menjadikan kepedulian sosial perusahaan sebagai unsur yang ditawarkan kepada masyarakat. Perencanaan kegiatan sosial perusahaan yang akan dijalankan harus selalu masuk dalam agenda strategis perusahaan, meskipun kegiatan tersebut adalah dalam bentuk investasi. ${ }^{15}$

Dalam kegiatan bisnis membutuhkan etika, karena mengingat saat ini, sebagian besar manusia sebagai pelaku usaha mulai kehilangan rasa empati terhadap masyarakat di sekitarnya. Mereka lebih mementingkan kepentingan bisnis yang dijalankan tanpa memikirkan masyarakat di sekitar kegiatan bisnis mereka yang secara langsung maupun tidak langsung terkena dampak dari aktivitas bisnis yang dijalankannya.

Akibatnya, apabila manusia sebagai pelaku usaha tidak menjalankan etika bisnis, maka dampak yang dapat diterima adalah reputasi dan kepercayaan dari masyarakat terhadap kegiatan bisnis pelaku usaha tersebut menjadi tidak baik. Hal ini sejalan dengan tanggungjawab sosial perusahaan yang dapat menjaga kinerja perusahaan dalam jangka panjang. Karena etika bisnis merupakan pola bisnis yang tidak hanya peduli pada profitabilitasnya saja, tetapi juga memperhatikan kepentingan stakeholder-nya. Etika bisnis tidak bisa terlepas dari etika personal, keberadaan mereka merupakan kesatuan yang tidak terpisahkan dan keberadaannya saling melengkapi.

Dilihat dari perspektif pandang hukum bisnis, ada 2 (dua) tanggungjawab dalam etika bisnis, yaitu tanggung jawab hukum secara perdata dan pidana, dan aspek tanggung jawab sosial yang dibangun di atas landasan norma moral yang berlaku di dalam masyarakat. Hal ini mempunyai arti bahwa, meskipun suatu kegiatan bisnis secara hukum tidak melanggar peraturan perundang-undagan yang berlaku, tetapi aktifitas bisnis tersebut dilakukan dengan melanggar moral masyarakat atau merugikan masyarakat, maka bisnis tersebut dianggap sebagai perbuatan yang melanggar norma etika atau perbuatan yang tidak etis.

${ }^{15}$ Ibid., hlm. 9. 
Penerapan CSR oleh perusahaan berarti bahwa perusahaan bukan hanya merupakan entitas bisnis yang hanya berusaha mencari keuntungan semata, tetapi perusahaan itu merupakan satu kesatuan dengan keadaan ekonomi, sosial, dan lingkungan di mana perusahaan beroperasi. Direksi dan pegawai perusahaan seharusnya lebih menyadari pentingnya CSR karena CSR dapat memberikan perlindungan hak asasi manusia bagi buruh dan perlindungan lingkungan bagi masyarakat sekitar dan juga para pekerjanya. ${ }^{16}$

Etika bisnis merupakan tuntunan perilaku bagi dunia usaha untuk bisa membedakan mana yang boleh dilakukan dan mana yang tidak boleh dilakukan. Oleh sebab itu, maka dalam pemenuhan etika bisnis tidak hanya keuntungan yang menjadi tujuan utama, akan tetapi pemberdayaan masyarakat sekitar perusahaan, juga harus menjadi prioritas perusahaan. Hal tersebut dilakukan karena etika bisnis merupakan salah satu perwujudan dari Good Corporate Governance oleh perusahaan terhadap para pemangku kepentingan (stakeholder).

Sampai sekarang negara-negara di dunia belum dibuat peraturan yang mewajibkan adanya pelaksanaan CSR bagi perusahaan-perusahaan yang berada di negaranya masing-masing. Memang salah satu perkembangan topik CSR adalah perdebatan mengenai perlu atau tidaknya regulasi CSR dibuat. Saat ini, secara umum regulasi CSR masih dilakukan bersifat sukarela (voluntary). Negaranegara di Eropa, dijadikan sebagai tempat acuan penerapan CSR, dimana bahwa dalam penerapannya masih bersifat sukarela. Namun, perkembangan inisiatif praktek CSR di masing-masing negara berbeda-beda.

Di dalam CSR terdapat bentuk kerjasama antara perusahaan (tidak hanya Perseroan Terbatas) dengan segala sesuatu atau segala hal yang secara langsung maupun tidak langsung berinteraksi dengan perusahaan tersebut, termasuk aspek sosial dan lingkungannya, untuk menjamin keberadaan dan kelangsungan usaha perusahaan tersebut.

Manfaat CSR bagi perusahaan adalah ${ }^{17}$ 1) mempertahankan dan mendongkrak reputasi serta citra merek perusahaan; 2) mendapatkan lisensi

${ }^{16}$ Kristina K. Hermann, "Corporate Social Responsibility and Sustainable Development: The European Union Initiative as a Case Study”, 11 Indiana Journal of Global Legal Studies, 2004, hlm. 206. Sebagaimana dikutip Ridwan Khairandy, Ibid.

${ }^{17}$ Hendrik Budi Untung, Corporate Social Responsibility, Penerbit Sinar Grafika, Jakarta, 2008, hlm. 1. 
untuk beroperasi secara sosial; 3) mereduksi risiko bisnis perusahaan; 4) melebarkan akses sumber daya bagi operasional usaha; 5) membuka peluang pasar yang lebih luas; 6) mereduksi biaya, misalnya terkait dampak pembuangan limbah; 7) memperbaiki hubungan dengan stakeholders; 8) memperbaiki hubungan dengan regulator; 9) meningkatkan semangat produktivitas karyawan; 10) peluang mendapatkan penghargaan.

Di Indonesia, ada 2 (dua) instrumen hukum yang mewajibkan sebuah perusahaan untuk melakukan tanggung jawab sosial, di mana sebelum UU PT yang baru lahir, juga sebelumnya telah diatur di dalam Undang-Undang Nomor 25 Tahun 2007 tentang Pasar Modal. ${ }^{18}$

Di dalam Undang-Undang Nomor 25 Tahun 2007 tentang Pasar Modal (selanjutnya disebut UUPM), menyebutkan bahwa setiap penanam modal berkewajiban melaksanakan tanggung jawab sosial perusahaan. 19 Pada penjelasannya disebutkan yang dimaksud dengan tanggung jawab sosial perusahaan adalah tanggung jawab yang melekat pada setiap perusahaan penanaman modal untuk tetap menciptakan hubungan yang serasi, seimbang, dan sesuai dengan lingkungan, nilai, norma dan budaya masyarakat setempat. ${ }^{20}$

Sedangkan ketentuan yang berkaitan dengan CSR di dalam UU PT, terdapat pada Pasal 1 angka $3^{21}$ dan Pasal 74. Pasal 74 UUPT ini menyatakan: pertama, Perseroan yang menjalankan kegiatan usahanya di bidang dan/atau berkaitan dengan sumber daya alam wajib melaksanakan tanggung jawab sosial dan lingkungan; kedua, tanggung jawab sosial dan lingkungan sebagaimana dimaksud pada ayat (1) merupakan kewajiban perseroan yang dianggarkan dan diperhitungkan sebagai biaya perseroan yang pelaksanaannya dilakukan dengan memperhatikan kepatutan dan kewajaran; Ketiga, Perseroan yang tidak melaksanakan kewajiban sebagaimana dimaksud pada ayat (1) dikenakan sanksi sesuai dengan ketentuan peraturan perundang-undangan; dan Keempat,

${ }^{18}$ Lihat juga Erman Rajagukguk, "Konsep dan Perkembangan Pemikiran tentang Tanggung Jawab Sosial Perusahaan," Jurnal Hukum, Fakultas Hukum Universitas Islam Indonesia, Vol. 15 Nomor 2, April 2008, hlm.169-328.

${ }^{19}$ Pasal 15 huruf b UU PM

${ }^{20}$ Penjelasan Pasal 15 huruf b UU PM

${ }^{21}$ Tanggung Jawab Sosial dan Lingkungan adalah Komitmen perseroan untuk berperan serta dalam pembangunan ekonomi berkelanjutan guna meningkatkan kualitas kehidupan dan lingkungan yang bermanfaat, baik bagi perseroan sendiri, komunitas setempat, maupun masyarakat pada umumnya. 
Ketentuan lebih lanjut mengenai tanggung jawab sosial dab lingkungan diatur dengan Peraturan pemerintah.

Substansi dalam ketentuan Pasal 74 UU PT mengandung makna, mewajibkan TJSL mencakup pemenuhan peraturan perundangan terkait, penyediaan anggaran TJSL, dan kewajiban melaporkannya. ${ }^{22}$ Sesungguhnya rumusan itu sudah mengalami penghalusan lantaran kritikan keras para pelaku usaha. Semula, TJSL tidak hanya berlaku untuk perusahaan yang bergerak di bidang atau berkaitan dengan sumber daya alam, tetapi berlaku untuk semua perusahaan, tidak terkecuali perusahaan skala Usaha Kecil Menengah (UKM) baru berdiri, atau masih dalam kondisi merugi.

Secara umum dapat dinyatakan bahwa kewajiban CSR terhadap seluruh perseroan terbatas sebagaimana yang diatur dalam UU PT adalah hal yang tidak tepat dan belum jelas. Salah satu penyebab utamanya adalah bahwa penambahan bab dan pasal yang mewajibkan CSR itu tidak dihasilkan dari sebuah proses konsultasi publik yang memadai. Anggota-anggota DPR yang menyusun UU PT ini bukanlah para pakar CSR, namun mereka mengabaikan atas, pertama, masukan pemangku kepentingan utama, yaitu perusahaan, yang akan terkena dampak pemberlakuan peraturan tersebut, dan kedua, fakta bahwa sudah banyaknya pihak di luar Gedung DPR yang memiliki pengetahuan mengenai CSR jauh melampaui mereka, sehingga seharusnya bisa diundang untuk memberikan masukan. Sehingga konsep CSR yang ada di dalam UU PT adalah lemah, dan juga tidak dibuat berdasarkan pemahaman atas realitas dunia usaha Indonesia.

UU PM yang digunakan sebagai rujukan kewajiban CSR dalam UU PT, di penjelasan Pasal 15 huruf b, CSR didefinisikan sebagai “tanggung jawab yang melekat pada setiap perusahaan untuk tetap menciptakan hubungan yang serasi, seimbang, dan sesuai dengan lingkungan, nilai, norma, dan budaya masyarakat setempat." Sedangkan pada Pasal 1 angka 3 UU PT, CSR diterjemahkan sebagai "Tanggung Jawab Sosial dan Lingkungan adalah Komitmen perseroan untuk berperan serta dalam pembangunan ekonomi berkelanjutan guna meningkatkan

${ }^{22}$ Sutan Remy Sjahdeini, “Corporate Social Responsibility”, Jurnal Hukum Bisnis, Volume 26-No. 3 Tahun 2007, hlm. $65-66$. 
kualitas kehidupan dan lingkungan yang bermanfaat, baik bagi perseroan sendiri, komunitas setempat, maupun masyarakat pada umumnya."

Dari 2 definisi tersebut di atas adanya perbedaan definisi dan terminologi yang digunakan oleh UU PM dan UU PT. Perbedaan terminologi tersebut menjadi hambatan setiap perusahaan menerjemahkan dalam teknis pelaksanaannya, karena, pertama, istilah yang digunakan dalam UU PM adalah tanggung jawab sosial perusahaan, sedangkan istilah dalam UU PT adalah tanggung jawab sosial dan lingkungan.

Kedua, kata "komitmen perseroan" dan "tanggung jawab yang melekat" tidak dapat diartikan sama. Frasa "komitmen perseroan" juga membingungkan. Apa yang mau kita artikan dari kata komitmen? Ketiga, UU PT berorientasi pada peningkatan kualitas hidup masyarakat, sedangkan UU PM lebih berorientasi menciptakan hubungan yang serasi. Selain itu juga soal "pembangunan ekonomi berkelanjutan," apakah ini dimaksudkan sebagai ranah ekonomi saja dari pembangunan berkelanjutan? Padahal, konvergensi CSR dengan pembangunan berkelanjutan tidak memungkinkan lagi kita bisa menerima adanya ketimpangan di antara ketiganya. Keempat, pihak yang menjadi sasaran CSR dalam dokumen kerja UU PT adalah "...Perseroan sendiri, komunitas setempat, maupun masyarakat pada umumnya" yang selain tidak komprehensif sebagai senarai pemangku kepentingan, juga berbahaya karena tidak membatasinya dalam wilayah dampak.

Lebih menarik lagi ternyata terdapat inkonsistensi antara Pasal 1 dengan Pasal 74 serta penjelasan Pasal 74 itu sendiri. Pada Pasal 1 UU PT memuat “... komitmen Perseroan Terbatas untuk berperan serta", sedangkan Pasal 74 ayat (1) “... wajib melaksanakan Tanggung Jawab Sosial dan Lingkungan". Pada Pasal 1 mengandung makna pelaksanaan CSR bersifat sukarela sebagai kesadaran masing-masing perusahaan atau tuntutan masyarakat. Sedangkan Pasal 74 ayat (1) bermakna suatu kewajiban. Lebih jauh lagi kewajiban CSR pada Pasal 74 ayat (1) tidak memiliki keterkaitan langsung dengan sanksinya pada Pasal 74 ayat (3). Sanksi apabila tidak melaksanakan tanggung jawab sosial dan lingkungan tidak diatur dalam UU PT tetapi digantungkan kepada peraturan perundangundangan lain yang terkait. 
Demikian juga pada Pasal 74 tersirat bahwa PT yang terkena tanggung jawab sosial dan lingkungan dibatasi, namun dalam penjelasannya dapat diketahui bahwa semua perseroan terkena kewajiban TJSL, karena penjelasan Pasal 74 menggunakan penafsiran yang luas. Hal ini dapat dilihat pada bunyi Pasal 74 ayat (1) di mana perseroan yang menjalankan kegiatan usahanya dibidang dan/atau berkaitan dengan sumber daya alam wajib melaksanakan tanggung jawab sosial dan lingkungan, sedangkan pada penjelasan Pasal 74 menyatakan bahwa yang dimaksud dengan perseroan yang menjalankan kegitan usahanya di bidang sumber daya alam adalah perseroan yang kegiatan usahanya mengelola dan memanfaatkan sumber daya alam. Berikutnya yang dimaksud dengan perseroan yang menjalankan usahanya berkaitan dengan sumber daya alam adalah perseroan yang tidak mengelola dan tidak memanfaatkan sumber daya alam tetapi kegiatan usahanya berdampak pada fungsi sumber daya alam. Dengan demikian jelas tidak ada satupun perseroan terbatas yang tidak berkaitan atau tidak memanfaatkan sumber daya.

\section{Politik Hukum Pemberlakuan Prinsip CSR Dalam Pembaharuan UU PT}

Pasal 74 tentang CSR muncul pada saat pembahasan di tingkat Panitia Khusus (Pansus) DPR. Pada konsep awal yang diajukan pemerintah, tidak ada pengaturan seperti itu. Saat dengar pendapat dengan Kamar Dagang dan Industri (Kadin) dan para pemangku kepentingan lain, materi Pasal 74 ini pun belum ada. ${ }^{23}$ Begitu disayangkan bahwa hal yang sepenting CSR ini awalnya tidak ada dalam Rancangan UU PT yang dikirim Pemerintah ke DPR, sehingga tidak benarbenar dipersiapkan dengan seksama dan tanpa pembahasan atau public hearing dengan pengusaha sumber daya alam. Sehingga CSR muncul dari spontanitas para politisi di Senayan sehingga ada gurauan CSR adalah "Cuma Slogan \& Rekayasa". Dari versi pemerintah, saat itu, menjelaskan, aslinya pasal tentang CSR adalah usulan DPR. Bahkan informasi dari salah seorang Pansus Rancangan UU PT, menyebut bahwa ada 2 fraksi yang mengusulkan Pasal tentang CSR.

${ }^{23}$ www.madani-ri.com/pengaturan csr dalam uupt/diakses 30 Desember 2009 
Inilah yang menjadi kontraproduktif dan mengibiri peran masyarakat dan atau pelaku usaha (korporasi) yang nantinya menjadi sasaran pemberlakuan regulasi tersebut, karena beberapa informasi mengatakan bahwa anggota dewan yang membahas tentang CSR ini bukan pakar atau ahli dalam CSR yang mengetahui dan memahami bagaimana sebuah konsep CSR yang sebenarnya. Para wakil rakyat tersebut mengabaikan dan bahkan tidak "mendengarkan" pendapat dari pelaku usaha (korporasi) dan tidak meminta penjelasan sebagai bahan masukan dari pakar yang mengetahui dan memahami konsep CSR.

Padahal dalam prosesnya, seharusnya terdapat akses pengaruh bagi perusahaan dan masyarakat dalam penyusunan regulasi berkaitan dengan CSR. Keterlibatan perusahaan dan masyarakat dalam mempengaruhi penyusunan regulasi dapat dilakukan melalui konsultasi publik. Konsultasi publik ini diperlukan sebab konsultasi publik merupakan proses yang berbasiskan kesetaraan pemangku kepentingan dan bersifat dua (bahkan multi arah), berbeda dengan sosialisasi yang timpang dan searah. Dengan konsultasi publik, perusahaan dan masyarakat telah terlibat sejak awal mempengaruhi penyusunan regulasi.

Dengan tidak dilakukannya proses konsultasi publik oleh penyusun peraturan perundang-undangan tersebut dapat berakibat norma-norma yang mengatur tentang CSR ini "bertentangan" dengan konsep dasar CSR yang sebenarnya. Jika dicermati juga adanya inkonsistensi dalam UU PT antara Pasal 1 dengan Pasal 74 serta penjelasan Pasal 74 itu sendiri. Selain itu juga tidak jelasnya definisi mengenai CSR serta pemangku kepentingan dan mereka juga tampak tidak paham mengenai perdebatan sifat sukarela dan wajib dari CSR.

Belum lagi permasalahan tentang keberadaan aturan-aturan di atas yang membuat pencantuman Pasal 74 dalam UU PT terkesan mubazir dan dipaksakan. Sekilas terlihat, pembentukan dan pencantuman pasal ini bersifat "mencari popularitas" mengingat pembahasan Rancangan UU PT ini tidak jauh berselang setelah terjadinya kasus lumpur panas di Sidoarjo. Melalui Pasal 74 ini, legislator di DPR seperti memilih jalan keluar untuk "menghukum" semua perusahaan walaupun hanya satu perusahaan, yaitu Lapindo, yang melakukan kesalahan ketika itu. 
Dari hal-hal tersebut, nampak bahwa penguasa negara dalam bidang perundang-undangan (Pemerintah dan DPR), memberikan kesan bahwa mereka "telah" berusaha untuk mengakomodir sebuah regulasi yang responsif atau populistik dengan tetap menjunjung demokratis (bukan otoriter). Mereka ingin "menunjukkan" kepada publik bahwa produk hukum yang dihasilkan sangat mencerminkan rasa keadilan dan memenuhi harapan masyarakat (produk hukum yang responsif atau populistik).

Penguasa negara berusaha untuk "menggiring" opini publik dan memberikan baik kepada mereka dikarenakan pembuatan hukumnya sangat partisipatif (mengundang peran masyarakat) dan mencerminkan aspirasi masyarakat (karakter produk hukum yang responsif atau populistik). Disamping itu juga sebenarnya pembaharuan UU PT secara umum telah masuk dalam program legislasi nasional (Prolegnas) sejak tahun 2005.

Namun disayangkan, pembentuk undang-undang (Pemerintah dan DPR) tidak mengetahui dan memahami secara komprehensif tentang makna CSR yang sebenarnya, apakah CSR bersifat sukarela (voluntary) atau wajib (mandatory). Hal ini terbukti bahwa lingkup dan pengertian tanggung jawab sosial dan lingkungan yang dimaksud Pasal 74 UU PT berbeda dengan lingkup dan pengertian CSR dalam pustaka maupun definisi resmi yang dikeluarkan oleh lembaga internasional (The World Bank, ISO 26000 dan sebagainya) serta praktek yang telah berjalan di tanah air maupun yang berlaku secara internasional.

Inkonsistensi antar pasal dalam UU PT khususnya yang mengatur tentang CSR sangat membingungkan bagi para pihak yang akan terkena dampak pengaturan CSR ini. Ini bertolak belakang dengan karakter produk hukum yang responsif atau populistik, di mana produk hukum yang dihasilkan membatasi terjadinya penafsiran-penafsiran secara sepihak oleh pemerintah. Hal ini lebih cenderung kepada karakteristik produk hukum yang konservatif atau ortodoks yang terbuka kemungkinan untuk ditafsirkan oleh pemerintah secara sepihak (interpretatif, membuka peluang besar untuk ditafsirkan dengan peraturan pelaksanaan).

Pada tahun 2009 beberapa orang memohonkan uji materiil terhadap Pasal 74 ayat (1), (2) dan (3) UU PT ke Mahkamah Konstitusi. Tetapi, Mahkamah Konstitusi 
memberikan putusan, menolak permohonan para Pemohon uji materiil tersebut, sehingga CSR tetap merupakan kewajiban bagi perseroan yang menjalankan kegiatan usahanya di bidang dan/atau berkaitan dengan sumber daya alam. ${ }^{24}$

Namun demikian, hal tersebut bukan menjadikan konsep mandatory CSR Indonesia sudah benar-benar dapat dilaksanakan dengan baik. Konsep mandatory CSR Indonesia meninggalkan kerancuan dan perdebatan panjang serta masih terbuka ruang bagi perseroan-perseroan untuk menghindari kewajiban CSR mereka. Kerancuan konsep mandatory dapat diteliti dalam Pasal 74 ayat (1), (2) dan (3) UU PT. Penormaan Pasal 74 ayat (1) sudah secara jelas bahwa CSR wajib hukumnya bagi perseroan yang menjalankan kegiatan usahanya di bidang dan/atau berkaitan dengan sumber daya alam, yang dikuatkan oleh ayat (2) yang menyatakan bahwa sebagai wujud konkret kewajiban CSR, perseroan harus memasukkan dana CSR di dalam anggaran perseroan dan diperhitungkan sebagai biaya. Akan tetapi, timbul kerancuan yang disebabkan penormaan pada ayat (3) terhadap ayat sebelumnya, yang menyatakan bahwa Perseroan yang tidak melaksanakan kewajiban sebagaimana dimaksud pada ayat (1) dikenai sanksi sesuai dengan ketentuan peraturan perundang-undangan. Pada ayat (3) ini, bukanlah kelanjutan atau penguatan konsep mandatory yang mengatur tentang kewajiban perseroan menganggarkan dana CSR sebagai biaya sebagaimana yang diamanatkan oleh ayat (2), tetapi, ayat ini mengatur tentang kewajiban lain, yaitu kewajiban perseroan untuk mematuhi aturan tentang tanggung jawab perseroan sebagaimana yang tertera di dalam peraturan perundang-undangan tertentu. Sebagai contoh, sebuah perseroan pertambangan dalam aktivitasnya meninggalkan kerusakan pada lingkungan yakni

${ }^{24}$ Putusan Mahkamah Konstitusi diputuskan tidak secara bulat. Ada 3 (tiga) hakim konstitusi yang menyatakan pendapat berbeda (dissenting opinion). Mereka adalah Maria Farida, Maruarar Siahaan dan M. Arsyad Sanusi. M. Arsyad Sanusi berpendapat bahwa istilah CSR memang telah dikenal diberbagai negara di dunia, tetapi belum ada satu definisi pun yang telah disepakati. Ada beberapa pihak yang memahami dan menerjemahkan CSR dengan istilah Tanggung Jawab Sosial, akan tetapi tidak sedikit yang menerjemahkan CSR dengan istilah Tanggung Jawab Sosial dan Lingungan. Sedangkan Maria Farida menggarisbawahi kata "komitmen" yang sama sekali tidak mengindikasikan suatu kewajiban yang diharuskan negara, karena suatu komitmen berasal dari diri yang akan melakukannya, bukan berasal dari luar. Sehingga apabila komitemen tersebut kemudian ditetapkan sebagai "kewajiban", maka hal itu bukan lagi barasal dari dalam diri (bersifat sukarela), namun berasala dari luar diri yang melakukan (bersifat memaksa). Maria Farida melihat ketidaksinkronan atau contradiction in terminis ketika Pasal 1 angka 3 UU PT menyebutkan TJSL sebagai "komitmen" dengan Pasal 74 UU PT yang mewajibkan TJSL, sehingga menimbulkan ketidakpastian hukum. Ketiga hakim berpendapat pengaturan CSR harusnya bersifat sukarela, bukan merupakan kewajiban bagi perusahaan. Pelaksanaan tanggung jawab sosial sangat erat kaitannya dengan masalah etis, moral dan kepatutan, sehingga bersifat voluntary. 
terlanggarnya baku mutu air limbah, baku mutu emisi, atau baku mutu gangguan tambang dalam operasinya, maka kewajiban hukum atau sanksi yang akan dijatuhkan kepada perseroan tersebut adalah sanksi yang termaktub di dalam Undang-Undang Nomor 32 Tahun 2009 tentang Perlindungan dan Pengelolaan Lingkungan Hidup.

Kehadiran peraturan pelaksanaan CSR yang ditunggu-tunggu, sebagaimana diamanatkan oleh UU PT, baru hadir sekitar 5 (lima) tahun sejak diamanatkan, melalui Peraturan Pemerintah Nomor 47 Tahun 2012 tentang Tanggung Jawab Sosial dan Lingkungan Perseroan Terbatas (selanjutnya disebut PP TJSL PT). Pada prinsip idealnya, PP TJSL PT dibuat untuk menjawab atau memperjelas kerancuan konsep mandatory CSR dan memperkuat konsep yang tersurat di dalam Pasal 74 ayat (1) dan (2) UU PT dan sudah diperkuat oleh putusan Mahkamah Konstitusi. 25

25Putusan Mahkamah Konstitusi (MK) Nomor 53/PUU-VI/2008, pertama, menjadikan TJSL sebagai suatu kewajiban hukum melalui rumusan Pasal 74 merupakan kebijakan hukum dari pembentuk UU untuk mengatur dan menerapkan TJSL dengan suatu sanksi menjadikan TJSL sebagai suatu kewajiban hukum melalui rumusan Pasal 74 merupakan kebijakan hukum dari pembentuk UU untuk mengatur dan menerapkan TJSL dengan suatu sanksi, dan hal ini adalah benar, karena 1) Secara faktual, kondisi sosial dan lingkungan telah rusak di masa lalu ketika perusahaan mengabaikan aspek sosial dan lingkungan sehingga merugikan masyarakat sekitar dan lingkungan pada umumnya;2) Budaya hukum di Indonesia tidak sama dengan budaya hukum negara lain, utamanya negara industri maju tempat konsep CSR pertama kali diperkenalkan di mana CSR bukan hanya merupakan tuntutan bagi perusahaan kepada masyarakat dan lingkungannya tetapi juga telah dijadikan sebagai salah satu indikator kinerja perusahaan dan syarat bagi perusahaan yang akan go public. Dengan kata lain, MK tampaknya berpendapat bahwa sesuai kultur hukum Indonesia, penormaan TJSL sebagai norma hukum yang diancam dengan sanksi hukum merupakan suatu keharusan demi tegaknya TJSL atau CSR. 3) Menjadikan TJSL sebagai kewajiban hukum dinilai oleh MK justru untuk memberikan kepastian hukum sebab dapat menghindari terjadinya penafsiran yang berbeda-beda tentang TJSL oleh perseroan sebagaimana dapat terjadi bila TJSL dibiarkan bersifat sukarela. Hanya dengan cara memaksa tersebut akan dapat diharapkan adanya kontribusi perusahaan untuk ikut meningkatkan kesejahteraan masyarakat. Kedua, Mahkamah Konstitusi berpendapat bahwa Pasal 74 tidak menjatuhkan pungutan ganda kepada perseroan sebab biaya perseroan untuk melaksanakan TJSL berbeda dengan pajak._Lebih jauh, disebutkan oleh MK bahwa pelaksanaan TJSL didasari oleh kemampuan perusahaan, dengan memerhatikan kepatutan dan kewajaran, yang pada akhirnya akan diatur lebih lanjut oleh PP. Demikian pula tentang sanksi bagi perseroan yang tidak melaksanakan TJSL, MK berpendapat bahwa Pasal 74 ayat (3) yang merujuk pada sanksi hukum yang terdapat pada perundang-undangan sektoral merupakan rumusan yang tepat dan justru memberikan kepastian hukum, bila dibandingkan kalau UU PT menetapkan sanksi tersendiri. Jadi, MK tidak sependapat dengan para pemohon yang mengatakan adanya berbagai pasal dalam perundang-undangan yang juga mengatur tentang TJSL mengakibatkan ketidak-pastian hukum dan tumpang tindih sehingga tidak dapat mewujudkan TJSL yang efisien berkeadilan. Khusus tentang perundang-undangan yang tumpang tindih ini akan penulis bahas pada bagian 4 dari artikel ini. Ketiga, MK menilai bahwa norma hukum yang mewajibkan pelaksanaan TJSL oleh perusahaan tidak berarti meniadakan konsep demokrasi ekonomi yang berintikan pada efisiensi berkeadilan seperti diatur dalam Pasal 33 ayat (4) UUD 1945 dan tidak akan membuat TJSL sekedar formalitas perusahaan saja, sebab: 1) Prinsip demokrasi ekonomi memberi kewenangan kepada Negara untuk tidak hanya menguasai dan mengatur sepenuhnya kepemilikan dan pemanfaatan bumi, air, dan kekayaan alam, serta untuk memungut pajak semata, melainkan juga kewenangan untuk mengatur pelaku usaha agar mempunyai kepedulian terhadap lingkungan. 2) Pelaksanaan TJSL menurut Pasal 74 tetap akan dilakukan oleh perseroan sendiri sesuai prinsip kepatutan dan kewajaran, Pemerintah hanya berperan sebagai pemantau. Dengan demikian, tak perlu dikhawatirkan akan terjadi penyalah-gunaan dana TJSL ataupun membuat perseroan melaksanakan TJSL hanya sebagai formalitas belaka. 3) Pengaturan TJSL dalam 
Peraturan Pemerintah yang menjadi kunci pelaksanaan Undang-undang ini seharusnya mencerminkan Pancasila dan Undang-Undang Dasar Negara Republik Indonesia 1945. Ada 3 prinsip yang dijadikan dasar pembahasan CSR dalam RUU Perseroan Terbatas yaitu (1) prinsip pembangunan berkelanjutan, (2) prinsip negara kesejahteraan yang merupakan nilai-nilai hak ekonomi di dalam Pasal 33 UUD 1945 dan di alenia keempat Pembukaan Undang-Undang Dasar (3) nilai-nilai hukum yang hidup yang didasarkan pada Pancasila. ${ }^{26}$ Berdasarkan pandangan sistemik, maka dalam sistem hukum nasional setiap bidang hukum wajib bersumber dari Pancasila dan UUD 1945.27

Alinea kedua UUD 1945 menyatakan bahwa negara bertujuan menciptakan keadilan sosial bagi seluruh rakyat, dalam rangka mewujudkan negara yang merdeka, bersatu, berdaulat, adil, dan makmur. Dalam hal ini, negara berkewajiban memajukan kesejahteraan umum, mencerdaskan kehidupan bangsa, dan ikut melaksanakan ketertiban dunia yang berdasarkan kemerdekaan, perdamaian abadi, dan keadilan sosial. Pokok pikiran kedua ini identik dengan sila ke-5 Pancasila. ${ }^{28}$

Sementara, sila keadilan sosial bagi seluruh rakyat Indonesia diliputi dan dijiwai oleh sila pertama sampai dengan sila ke-4 Pancasila. Keadilan sosial bagi seluruh rakyat Indonesia mengandung arti, bahwa setiap orang Indonesia mendapat perlakuan yag adil dalam segala bidang, seperti hukum, politik,sosial,

bentuk norma hukum merupakan suatu cara Pemerintah untuk mendorong perusahaan ikut serta dalam pembangunan ekonomi rakyat.

${ }^{26}$ Lihat juga Konsiderans UU PM, bagian menimbang huruf a. bahwa untuk mewujudkanmasyarakat adil dan makmur berdasarkan Pancasila dan UUD 1945 perlu dilaksanakan pembangunan ekonominasional yang berkelanjutan dengan berlandaskan demokrasi ekonomi untuk mencapai tujuan bernegara; lebih lanjut dalam penjelasan umum disebutkan : Salah satu tujuan pembentukan pemerintahan Negara adalah untuk memajukan kesejahteraan umum. Amanat tersebut, antara lain, telah dijabarkan dalam Pasal 33 UUD 1945 dan merupakan amanat konstitusi yangmendasari pembentukan seluruh peraturan perundang-undangan dibidang perekonomian. Konstitusi mengamanatkan agar pembangunan ekonomi nasional harus berdasarkan prinsip demokrasi yang mampu menciptakan terwujudnya kedaulatan ekonomi Indonesia. Risalah Rapat Panitia Khusus, Rancangan UU PT, Masa Sidang I , Jumat, 1 Desember 2006. Lihat juga Konsideran UU PT bagian mengingat :Pasal 5 ayat (1), Pasal 20, dan Pasal 33 UUD 1945; dalam penjelasan umum dapat dilihat : Pembangunan perekonomian nasional yang diselenggarakan berdasarkan demokrasi ekonomi dengan prinsip kebersamaan, efisiensi yang berkeadilan, berkelanjutan, berwawasan lingkungan, kemandirian, serta menjaga keseimbangan kemajuan dan kesatuan ekonomi nasional bertujuan untuk mewujudkan kesejahteraan masyarakat.

${ }^{27}$ Sunaryati Hartono, Politik Hukum Menigu Satu Sistem Hukum Nasional, Penerbit Alumni, Bandung, 1991, hlm. 64

28 Darji Darmodiharjo dan Shidarta, Pokok-Pokok Filsafat Hukum: Apa dan Bagaimana Filsafat Hukum Indonesia, Penerbit Gramedia Pustaka Utama, Jakarta,1995, hlm. 215-216 
ekonomi, dan kebudayaan. Makna dari keadilan sosial ini mencakup pula pengertian adil dan makmur. ${ }^{29}$

Namun, alih-alih untuk memperjelas dan menguatkan konsep mandatory atas kerancuan dalam penormaan di UU PT, PP TJSL PT, justru membuat konsep mandatory CSR Indonesia menjadi semakin tidak jelas. PP TJSL PT yang diharapkan sebagai aturan yang "menjelaskan" lebih jelas dan rinci tentang apa dan bagaimana CSR itu harus direncanakan/dianggarkan dan dilaksanakan serta siapa yang mengawasi, tidak kunjung memberikan kepastian hukum tentang konsep mandatory CSR untuk melengkapi aturan yang sudah ada.

Kenyataannya, tidak satupun kalimat di dalam PP TJSL PT yang memerintahkan perseroan untuk memasukkan dana CSR dalam anggaran biaya perseroan. PP TJSL PT memberikan sepenuhnya otonomi penganggaran itu kepada internal perseroan. ${ }^{30}$ Pada Pasal 4 ayat (1) PP TJSL PT, TJSL atau CSR dilaksanakan oleh direksi perseroan berdasarkan rencana kerja tahunan setelah mendapatkan persetujuan dewan komisaris atau Rapat Umum Pemegang Saham (RUPS). Hal ini bermakna, Pasal 4 ayat (1) ini menyerahkan sepenuhnya apakah menjadikan TJSL atau CSR wajib atau tidak kepada internal perusahaan (dewan komisaris atau RUPS). Pasal ini juga melepaskan kuasa negara untuk memaksa perseroan yang tidak memasukkan mata anggaran CSR di dalam daftar biayanya. Makna kehadiran PP TJSL PT sebenarnya adalah, CSR atau TJSL tidak lagi wajib bagi perseroan di Indonesia dan dalam praktiknya kelak aturan baru ini akan berpotensi menjadi alat pembenar tambahan bagi pengelola dan pemilik korporasi-korporasi yang selama ini tidak menjalankan kewajiban sosial mereka.

\section{Penutup}

Proses pembentukan UU PT, belum sepenuhnya mencerminkan karakteristik produk hukum yang responsif di tengah pusaran konfigurasi politik yang demokratis. Regulasi CSR dalam UU PT, secara praktik realistis menjadi

\footnotetext{
${ }^{29}$ Ibid., hlm. 220

${ }^{30}$ www.hukumonline.com, diakses 11 Desember 2008
} 
karakteristik hukum korporasi Indonesia tumpang tindih dengan hukum-hukum yang sudah ada.

Kehadiran PP TJSL PT atas CSR atau TJSL, semula diharapkan untuk memperjelas dan menguatkan konsep mandatory atas kerancuan dalam penormaan di UU PT, namun PP TJSL PT justru "memberikan ketegasan" bahwa CSR atau TJSL tidak lagi wajib bagi perseroan di Indonesia dan dalam praktiknya aturan ini berpotensi menjadi alat pembenar tambahan bagi pengelola dan pemilik korporasi-korporasi yang selama ini tidak menjalankan kewajiban sosial mereka.

Regulasi yang sudah telanjur mengikat semua pihak tersebut diharapkan dapat menjamin bahwa CSR harus memenuhi prinsip Good Corporate Government, yang mestinya didorong melalui pendekatan etika maupun pendekatan pasar (insentif). Pendekatan regulasi sebaiknya dilakukan untuk menegakkan prinsip transparansi dan keadilan dalam kaitan untuk menyamakan level of playing field pelaku ekonomi.

\section{Daftar Pustaka}

Budi Untung, Hendrik, Corporate Social Responsibility, Penerbit Sinar Grafika, Jakarta, 2008.

CSR For Better Indonesia", Lingkar Studi CSR, Bandung, 19 April 2008

Darmodiharjo, Darji dan Shidarta, Pokok-Pokok Filsafat Hukum: Apa dan Bagaimana Filsafat Hukum Indonesia, Penerbit Gramedia Pustaka Utama, Jakarta,1995.

Erni, Ernawan, Business Ethics: Etika Bisnis, Penerbit CV. Alfabeta, Bandung, 2007.

Hartono, Sunaryati, Politik Hukum Menuju Satu System Hukum Nasional, Penerbit Alumni, Bandung, 1991

Hasibuan, "Pengaruh Karakteristik Perusahaan terhadap Pengungkapan Sosial", Tesis, Universitas Diponegoro, Semarang, 2001

Hidayat, Mohamad, "Pandangan Dunia Usaha terhadap Undang-Undang Nomor 40 Tahun 2007 tentang Perseroan Terbatas," dalam http://www.madaniri.com, 31 Oktober 2007, pandangan-dunia-usaha-terhadap-undangundang

Khairandy, Ridwan, Camelia Malik, Good Corporate Governance: Perkembangan Pemikiran dan Implementasinya di Indonesia Dalam Perspektif Hukum, Cetakan Pertama, Penerbit Kreasi Total Media Yogyakarta, 2007. 
Khairandy, Ridwan, "Corporate Social Responsibility: Dari shareholder Ke Stakeholder, dan Dari Etika Bisnis Ke Norma Hukum," makalah yang disampaikan pada Workshop Tanggungjawab Sosial Perusahaan, pada 6-8 Mei 2008, yang diselenggarakan kerjasama PUSHAM UII dengan Norsk Senter for Menneskerettigheter Norwegian Center for Human Rights

Rajagukguk, Erman, "Konsep dan Perkembangan Pemikiran tentang Tanggung Jawab Sosial Perusahaan," Jurnal Hukum, Fakultas Hukum Universitas Islam Indonesia, Volume 15 Nomor 2, halaman 169-328, Yogyakarta, April 2008

Redi, Panuju, Etika Bisnis, PT. Grasindo, Jakarta, 1995

Remy Sjahdeini, Sutan, “Corporate Social Responsibility:, Jurnal Hukum Bisnis, Volume 26-No. 3 Tahun 2007.

Suseno, Franz Magniz, Etika Dasar - Masalah-Masalah Pokok Filsafat Moral, Penerbit Kanisius, Yogyakarta, 1987

Susiloadi, Priyanto, "Implementasi Corporate Social Responsibility Untuk Mendukung Pembangunan Berkelanjutan," Jurnal Spirit Publik Volume 4, Nomor 2 Halaman: 123 - 130, Oktober 2008

Wibowo Jalal, Pamadi dan Sonny Sukada, "Perkembangan Mutakhir CSR di Indonesia: Antara Pasal 74 UUPT dan Draft 4.1. ISO 26000", makalah pada seminar "Widjaja, Gunawan \& Yeremia Ardi Pratama, Risiko Hukum dan Bisnis Perusahaan Tanpa CSR, Penerbit Forum Sahabat, Jakarta, Cetakan Pertama, Desember 2008.

Wijaya, Gunawan, Seri Pemahaman Perseroan Terbatas 150 Tanya Jawab Tentang Perseroan Terbatas, Cetakan Pertama, Forum Sahabat, Jakarta, 2008.

Wijaya Tunggal, Amin, Business Ethics dan Corporate Social Responsibility (CSR) Konsep dan Kasus, Havarindo, 2008

http:/ / pemberdayaan-lifeskill-csr.blogspot.com/2008/05/perdebatan-csrdimedia-bahan-bagi.html. diakses 16 Juli 2007

http://www.madani-ri.com/pengaturan-csr-dalam-uu-pt/ diakses 30 Desember 2009

www.hukumonline.com, diakses 11 Desember 2008

Undang-Undang Dasar 1945

Undang-Undang Nomor 40 Tahun 2007 tentang Perseroan Terbatas

Undang-Undang Nomor 25 tahun 2007 tentang Penanaman Modal (UUPM)

Peraturan Pemerintah Nomor 47 Tahun 2012 tentang Tanggung Jawab Sosial dan Lingkungan Perseroan Terbatas 